\title{
Sosyal Zekânın Akademik Performans Üzerindeki Etkisinde Kültürel Zekânın Düzenleyici Rolü
}

\section{Erol TEKIN ${ }^{1}$}

ÖZ: Bu çallşmanın amacı sosyal zekâ ve kültürel zekânın akademik performans üzerindeki etkisini incelemektir. Ayrica sosyal zekânın akademik performans üzerindeki etkisinde kültürel zekânın düzenleyici rolü araştırllmıştır. Bu amaç çerçevesinde Kastamonu Üniversitesi İktisadi ve İdari Bilimler Fakültesi'nde eğitim gören 329 adet yabancı uyruklu ögrenciye anket çalışması uygulanmıştır. Toplanan veriler doğrulayıc faktör analizi ve regresyon analizleri ile test edilmiştir. Analizler sonucunda sosyal zekâ ve kültürel zekânın öğrencilerin akademik başarllarl üzerinde etkili olduğu tespit edilmiştir. Düzenleyici etki analizi sonucunda ise, sosyal zekânın akademik performans üzerindeki etkisinde kültürel zekânın düzenleyici bir rolü olduğu bulgusuna ulaşılmışıtır.

Anahtar Kelimeler: Sosyal Zekâ, Kültürel Zekâ, Akademik Performans, Düzenleyici Rol Jel Kodlart: M10, M14, M19

\section{The Moderator Role of the Cultural Intelligence in The Effect of Social Intelligence on Academic Performance}

\begin{abstract}
The aim of this study is to examine the effect of social and cultural intelligence on academic performance. In addition, the moderating role of cultural intelligence in the effect of social intelligence on academic performance has been investigated. Within the scope of this aim, a questionnaire was applied to 329 foreign students at Kastamonu University Faculty of Economics and Administrative Sciences. The obtained data were analyzed by confirmatory factor analysis and regression analysis. As a result of the analyzes made, it is seen that social and cultural intelligence has a significant and positive effect on academic performance. As a result of the moderating impact analysis, it has been found that the cultural intelligence has a moderating role in the influence of the social intelligence on the academic performance.
\end{abstract}

Keywords: Social Intelligence, Cultural Intelligence, Academic Performance, Moderator Role

Jel Codes: M10, M14, M19

\footnotetext{
${ }^{1}$ Dr. Öğr. Üyesi, Kastamonu Üniversitesi, İktisadi ve İdari Bilimler Fakültesi, Uluslararası Ticaret ve Lojistik Yönetimi Bölümü, etekin@kastamonu.edu.tr, orcid.org/0000-0003-1166-7671.
} 


\section{Giriș}

Küreselleşme ile birlikte sadece iş hayatında değil toplumsal hayatın tüm alanlarında sınırlar ortadan kalkmıştır. Bu alanlardan bir tanesi de en önemli üretim kaynağı olan insan kaynağını yetiştiren eğitim alanıdır. Küreselleşmenin etkisi ile birlikte özellikle gelişmiş ülkelerdeki kalifiye insan gücü ihtiyacı gelişmekte olan ülkelerde daha kaliteli eğitim talebini arttırmaya başlamıştır. Bu durum özellikle geri kalmış ve gelişmekte olan ülkelerdeki yurt dışına giden yabancı öğrenci hareketliliğinin artmasına neden olmuştur. Bu hareketlilik çerçevesinde dikkat çeken önemli kavramlardan bir tanesinin kültür olduğu ifade edilebilir. Çünkü kültür; tarihsel ve toplumsal gelişim süreci içerisinde yaratılan her türlü değerler ile bunları kullanmada, sonraki kuşaklara iletmede kullanılan, insanın doğal ve toplumsal çevresine egemenliğinin ölçüsünü gösteren araçları ifade etmektedir (TDK, 2019). Bu nedenle küreselleşmenin getirdiği öğrenci hareketliliği farklı ülkelerde geçmişten süre gelen farklı kültürlerin bir arada yaşamasına zemin hazırlamaktadır. Özellikle yabancı bir ülkeye ve kültüre giden öğrencilerin hem ülkeye hem de söz konusu farklı kültürlere ayak uydururken aynı zamanda başarılı olmaları da gerekmektedir. Bu başarı hem geldikleri ülke için hem de eğitim alınan ülke için önemlidir. Çünkü geldikleri ülkeye dönen öğrenciler aldıkları eğitim ile ülkelerinde başarılı işlere imza atarak ülkenin ekonomik kalkınmasına katkı sağlamakta bununla birlikte eğitim aldıkları üniversitenin ise uluslararasılaşması ve bilinirliğinin artmasını sağlamaktadırlar. Fakat bu süreçte başta kültürel farklılıkların getirdiği bazı zorluklar birçok öğrencinin başarısız olmasına ve hem gittikleri üniversite için hem de geldikleri ülke için birer yük olarak algılanabilmektedir. Öyle ki, bir toplumun kendi içerisinde bile kültürel farklılıklar gözlenmekteyken, farklı toplumlarda, kültürel farklılıkların ortaya çıkması çok daha muhtemeldir (Koparan vd., 2016). Bu kapsamda yazın incelendiğinde kültürel zekâsı yüksek olan bireylerin yabancı kültür ve davranışa uyum sağlamak noktasında uygun strateji ve tutum belirleyebilecekleri düşünülebilir. Bu bireylerin sergilediği strateji ve tutumlar ise karşılarına çıkan güçlükler ile başarılı bir şekilde mücadele ederek performanslarını artırmasına neden olmaktadır (Ang vd., 2007; Ang ve Van Dyne, 2008; Livermore, 2011). Ayrıca küreselleşme ile birlikte kültürel zekânın yanında günümüz bilgi çağında önemli hususlardan bir tanesi halini alan sosyal zekâ kavramı da önemli hale gelmeye başlamıştır. Çünkü insanları anlama ve insan ilişkilerinde ustaca davranma olarak ifade edilen sosyal zekâ (Goleman, 2016) kültürel zekâ ile birleştiğinde söz konusu performansın daha da artacağ 1 beklenmektedir.

$\mathrm{Bu}$ bağlamda çalışmada Türkiye'de eğitim gören yabancı uyruklu öğrencilerin sosyal ve kültürel zekâ düzeyleri ile akademik başarıları arasındaki ilişki ele alınacaktır. Yazında kültürel ve sosyal zekânın farklı sektörlerde farklı konularda ele alındığı çalışmalara rastlamak mümkündür. Fakat özellikle son yıllarda yükseköğretimde uluslararasılaşma faaliyetlerine verilen önem dikkate alındığında hem kültürel zekânın hem de sosyal zekânın akademik başarıya etkisini inceleyen pek fazla çalışma yoktur. Bu nedenle hem ülkemize gelecek olan öğrencilere hem 
de ülkemizden başka ülkelere gidecek olan başta öğrenci, yönetici, iş adamı ve çalışanlar olmak üzere tüm bireylere yol göstermesi açısından çalışmanın alan yazına bir katkı sunacağı düşünülmektedir. Bu kapsamda çalışmanın giriş kısmını takip eden ilk bölümünde kültürel zekâ ve sosyal zekâ kavramlarına ilişkin kuramsal çerçeveden bahsedilecek, ikinci bölümde ise literatür taraması ele alınacaktır. Çalışmanın üçüncü bölümünde ise araştırmanın yöntemine değinilecektir. Son olarak çalışmaya ilişkin bulgular, sonuç ve öneriler ile çalışma sonlandırılacaktır.

\section{Kavramsal Çerçeve}

Son yıllarda özellikle çok kültürlü ortamlarda ve farklı kültürlere uyum sağlayarak yaşamın daha kaliteli ve başarılı bir şekilde devam edebilmesi bireyler ile oluşturulmuş olan ilişki ağlarının etkin bir biçimde yönetilmesi önem kazanmıştır. Çünkü herkes farklı kültürlerde ve çok kültürlü ortamlarda başarılı bir etkileşim kuramamaktadır. Söz konusu etkileşimi kurarak farklı kültürel ortamlarda başarı elde edilmesini sağlayan önemli kavramlardan bir tanesi kültür yazınında üzerinde sıklıklar durulmaya başlanan kültürel zekâ kavramıdır (Crowne, 2008).

İlk kez Earley ve Ang (2003) tarafından ortaya atılan kültürel zekâ kavramının kuramsal alt yapısı çok uzun bir geçmişe dayanmamaktadır. Fakat çok kültürlü ortamlarda kişiler arasındaki ilişkilerin nitelik ve etkinliğinin belirlenmesi noktasında ihtiyaç duyulan kavramsal eksikliği gideren bir kavram olarak ortaya çıkması açısından yazında önemli bir yere konulmaktadır. İlk ortaya çıktığı andan itibaren farklı değişkenlerle ele alınmaya başlanan kültürel zekâ ile ilgili birçok tanım geliştirildiği görülmektedir. Yapılan ilk tanımlamalarda kültürel zekâ kişinin yeni kültürel ortamlara etkili bir biçimde uyum gösterebilme kabiliyeti olarak tanımlanmaktadır (Earley ve Ang, 2003: 59). Daha geniş bir ifadeyle kültürel zekâ bireyin farklı kültüre sahip başka bireylerin hareketlerini, davranışlarını, ses ve mimiklerini, tonlamasını, vurgusunu, bireyin kendi kültüründen olan insanlar gibi anlayabilmesi, değerlendirmesi ve yorumlaması şeklinde ifade edilmektedir (Earley ve Mosakowski, 2004: 139). Thomas ve Inkson'a (2004) göre, çok yönlü bir yetkinlik olarak kültürel zekâ bireylerin kültürleri anlayarak buna uygun bir şekilde hareket etmesine neden olan bir yetenek olarak da ifade edilmektedir. Diğer bir araştırmaya göre kültürel zekâ kültürel farklılıkların olduğu ortamlarda etkin bir biçimde şekilde durumu kavrama, anlama ve duruma uygun davranışı sergileme yeteneklerine odaklanan özel bir zekâ şekli olarak tanımlanmıştır (Ang vd., 2007: 337). Başka bir tanımlama da ise, kültürel zekâ çok kültürlü ortamlarda sorunların etkili bir biçimde tanımlanmasını sağlayarak soru çözme becerisi kazandıran bir kavramdır (Livermore, 2013). Yapılan tanımlamaların ulusal, etnik ve örgütsel alanlar ile diğer kültür çeşitlerini de kapsadığını söylemek doğru olacaktır. Söz konusu tanımlamalarda da görüldüğ̈̈ üzere kültürel zekâ kültürlerarası araştırmalara ışık tutan bir kavramdır. Bu nedenle kültürel zekâ, neden bazı insanlar farklı ulus ve örgüt kültürlerinde başarılı iken bazıları başarısızdır sorusuna aranan cevabı verebileceği söylenebilir. 
Sosyal zekâ kavramı ise, ilk ortaya çıktığında insan ilişkilerinde ustaca davranarak insanları anlama ve idare etme yeteneği olarak tanımlamıştır (Thorndike, 1920). Yani sosyal zekâ insanlarla geçinme ve onlarla anlaşabilme becerisi olarak ifade edilebilir (Moss ve Hunt, 1927). İlk tanımlamalardan sonra sosyal zekâ kavramının tanımı biraz daha genişlemiştir. Bu kapsamda sosyal zekâ genel zekânın sosyal durumlara uygulanarak sosyal çevrede insanların hislerini, ruh hallerini, güdülerini doğru şekilde değerlendirme becerisi olarak tanımlanmıştır (Wedeck, 1947; Weschler, 1958). Sosyal zekâ, alternatif bir zekâ modeli geliştirme açısından önemlidir. Ayrıca sosyal zekânın ölçülmesi zordur. Bu zorluk sosyal zekânın genel zekâdaki sözel akıl yürütme becerisinden ayrılmasının zor oluşundan kaynaklanmaktadır (Doğan, 2006). İnsan ilişkilerinde iyi uyum sağlayan bir birey zeki olmalıdır ki mantıklı olarak düşünebilsin, amacına göre hareket etsin ve çevresiyle etkili bir şekilde iletişime geçebilsin. Bu iletişim kişinin sadece çevresi ile ilişkisini değil çalışma ortamları da dâhil olmak üzere okulda, iş yerinde ve tüm sosyal ortamlarında başarısını da arttıracaktır.

\section{Literatür Taraması}

İnsanların farklı kültürlerde etkin ve verimli bir biçimde çalışmaları ve faaliyette bulunmaları oldukça zordur. Öyle ki, son zamanlarda kültürün örgütsel davranış ve performans üzerindeki potansiyel etkisi popüler hale gelmiştir (İlhan Nas, 2006). Bununla birlikte kültürel farklılıkların, iş ortaklıklarında ortaklar arası bilgi akışını, çatışmayı, performansı etkilediği bilinene bir gerçekliktir (Demirbağ ve Mirza, 2000; Yan ve Child, 2004; İlhan Nas, 2007). Bu noktada kültürel zorlukları yenmek için kültürel zekâ önemli bir araç olarak ifade edilebilir (Yeşil, 2010). Yazın incelendiğinde kültür üzerine yapılan çalışmaların mevcut olduğu görülebilmektedir. Bu çalışmalar göstermiştir ki, insanların yaşamlarının devamı ve diğer kültürel ortamlarda bilgi değişimi yapmak için bazı sosyal ve bilişsel beceriler geliştirmelidir. $\mathrm{Bu}$ becerilerden en önemlileri diğer insanlar ile iletişim kurmak, onlardan öğrenmek ve diğerler insanların zihinlerini okumaktır (Herrmann vd., 2007: 1365). Bu kapsamda temelde çok kültürlü ortamlarda etkin bir biçimde uyum sağlama yeteneği olarak nitelendirilen (Huff vd., 2014) ve bireylerin çok kültürlerarası ortamlarda gerek günlük yaşamında gerekse de çalışma hayatı içerisinde başarılı olmasını sağlayan bir yetenek olarak görülen kültürel zekâ üzerine yapılan çalışmalara rastlamak mümkündür.

Kültürel zekâ farklı ve belirsiz kültürel ortamlarda olaylara ve duruma etkili bir yaklaşım sağlamaktadır (MacNab ve Worthley, 2012: 62). Lin'e (2012) göre, kültürel ortamlara sağlanacak iyi bir uyum süreci sayesinde iyi bir ruh sağlığ 1 , hayattan memnun olma, yerel halkla iyi ilişkiler kurma, iş ile uyumluluk, iş ile ilgili ortaya çıkabilecek farklı durumlar karşısında olumlu bir tutum sergileme yaklaşımı da sağlanacaktır. Bilgi ve teknoloji çağında ulaşılabilirliğin hızla arttı̆g 1 düşünüldügüunde başta iş dünyası olmak üzere neredeyse tüm alanlarda kültürlerin rolü artmıştır. Böyle bir ortamda ise ister doğuştan edinilmiş isterse de sonradan kazanılmış olsun kültürel zekânın önemi giderek artmaya başlamıştır (Peterson, 
2004: 84). Yazın incelendiğinde kültürel zekâsı yüksek olan bireylerin, diğerlerine göre daha fazla çabaladığı ve başarılı olduğu söylenebilir (Earley ve Mosakowski, 2004: 8). Kültürel zekâsı düşük olan bireylerin ise daha çok basma kalıpçı ve gereksiz çatışmacı oldukları görülebilmektedir (Alon ve Higgins, 2005: 506).

$\mathrm{Bu}$ bağlamda yabancı yazın incelendiğinde Wu ve Ang (2011) Singapur'da yaptıkları araştırmada gurbetçi kültürler arası destekleyici uygulamalar ile kültürel uyum ve performans arasındaki ilişkide kültürel zekânın düzenleyici rolünü incelemişlerdir. Çalışmanın örneklemini Singapur'da ikamet eden 169 gurbetçi oluşturmaktadır. Araştırma sonuçlarına göre meta-bilişsel ve bilişsel kültürel zekânın, gurbetçi destekleyici uygulamalar ile uyum arasındaki bağı olumsuz yönde etkilediği görülmüştür. Bununla birlikte motivasyonel kültürel zekânın ise olumlu yönden etkisi tespit edilmiştir. Eisenberg vd. (2013) çalışmalarında İşletme Fakültesi öğrencilerinin almış oldukları kültürlerarası yönetim dersinin kültürel zekâ düzeyini etkileyip etkilemediğini incelemişlerdir. Bu çalışmanın örneklemini 289 öğrenci oluşturmaktadır. Araştırma sonuçları söz konusu kültüreler arası yönetime ilişkin derslerin kültürel zekâyı arttırdığ (2012) çalışmasında kültürel zekâ ile iş performansı arasındaki ilişkide incelemişlerdir. Malezya'da çalışan 332 gurbetçi üzerinde gerçekleştirdikleri çalışmada kültürel zekâ düzeylerinin iş performansı etkilediğini ve kültürlerarası uyumun bu ilişkide aracılık rolü üstlendiğini tespit etmişlerdir. Jyoti ve Kour (2015) çalışmalarında kültürel zekânın görev performansı üzerindeki etkilerini incelemiş ve ilişkide kültürel uyumun aracı rolünü ele almışlardır. 225 yönetici çalışan üzerinde yapılan araştırma sonucunda kültürel zekânın görev performansını önemli ölçüde anlamlı ve olumlu yönde etkilediği ortaya çıkmıştır. Ayrıca kültürel uyumun bu ilişkide tam aracı rol üstlendiği de tespit edilmiştir. Vedadi vd. (2010) İran'da 78 yönetici üzerinde yaptıkları çalışmalarında kültürel zekânın başarı üzerindeki etkisini ele almışlardır. Araştırma sonucunda kültürel zekâ ile başarı arasında yüksek düzeyde anlamlı ilişki ortaya çıkmıştır. Duff vd. (2012) çalışmalarında kültürel zekâ ve görev performansı ilişkisini 52 farklı kültürden toplam 102 öğrenci üzerinde araştırmışlardır. Sonuçlar kültürel zekânın görev performansını arttırdığına kanıt sağlamıştır. Barakat vd. (2016) yılında yaptıkları çalışmada Brezilya'daki çok uluslu işletmelerde çalışan yöneticiler üzerinde gerçekleştirdikleri çalışmada kültürel zekânın iş tatmini ve performansına etkisini incelemişlerdir. Araştırma sonucunda kültürel zekânın hem iş tatminin hem de performansı olumlu ve anlamlı etkilediği sonucu ortaya çıkmıştır.

Yerli yazına bakıldığında ise eğitim ve sağlık sektörleri başta olmak üzere birçok alanda kültürel zekâ üzerinde çeşitli çalışmaların yapıldığı görülmektedir. Şahin ve Gürbüz (2012) çalışmalarında kültürel zekânın görev performansı ile olan ilişkisini ele almışlardır. Çalışmanın örneklemini içerisinde Türkiye'nin de bulunduğu 9 ülkede 121 çokuluslu ve çok kültürlü örgüt çalışanları oluşturmaktadır. Araştırma sonucu genel performansın anlaşılması açısından kültürel zekânın dikkate alınmasının gerekliliğini vurgulamaktadır. İşçi vd., (2013) sağlık sektöründe Sağlık Bakanlı̆̆ı'nın sınıflamasına göre A sınıfı 2 özel hastanede yaptıkları araştırmada 
hastane çalışanlarının kültürel zekâ düzeylerini incelemişlerdir. Araştırmanın örneklemini söz konusu 2 özel hastanedeki 150 çalışan oluşturmaktadır. Araştırma sonuçları örneklemin kültürel zekâ düzeyinin 3,93 olduğunu göstermektedir. Bununla birlikte kurumda ve meslekte çalışma süresinin kültürel zekâ ile negatif yönde anlamlı ve zayıf ilişkisi olduğu görülmüştür. Bezirgan vd. (2015) yapmış oldukları çalışmada ise Ayvalık, Burhaniye ve Edremit ilçelerinde turizm sektöründe faaliyette bulunan işletmelerde çalışan 617 kişiyi incelemişlerdir. Yaptıkları bu araştırmanın amacı ise kişilik özelliklerinin kültürel zekâ üzerindeki etkisini incelemektedir. Araştırma sonucunda her bir kişilik özelliğinin farklı kültürel zekâ boyutları üzerinde etkisi tespit edilmiştir. Ersoy ve Ehtiyar (2015) çalışmalarında kültürel zekâyı yöneticiler üzerinde incelemişlerdir. Yaptıkları araştırmanın amacı, yabancı yöneticilerin kültürel zekâsının kültürel farklılıkların yönetimi üzerindeki etkisini incelemektir. Araştırmanın amacına uygun olarak turizm sektöründe faaliyet gösteren 10 adet beş yıldız işletmede görev yapan yabanc1 genel müdürler ve onlara bağlı çalışan 27 Türk departman müdürüyle derinlemesine görüşmeler yapılmıştır. Araştırma sonuçları kültürel zekânın ve alt boyutlarının kültürel farklılıkların yönetimini olumlu yönde etkilediğini göstermektedir. Doğutaş (2015) yaptığı araştırmada öğretmen adayı üniversite öğrencileri üzerinde yaptıkları araştırmada öğretmen adaylarının kültürel zekâ düzeylerini tespit etmeyi amaçlamışlardır. Bu amaç çerçevesinde Türkiye'de bir üniversitede gerçekleştirdikleri çalışmanın örneklemini söz konusu üniversitenin eğitim fakültesinde 2014-2015 yılında öğrenim gören 450 öğretmen aday1 oluşturmaktadır. Araştırma sonucunda öğretmen adaylarının kültürel zekâ düzeyleri ile bazı sosyo-demografik değişkenler arasında anlamlı bir ilişki tespit etmişlerdir. Büyükbeşe ve Yıldız (2016) eğitim sektörü üzerinde gerçekleştirdikleri ve kültürel zekâyı ele aldıkları çalışmada kültürel zekânın yaşam doyumuna etkisini incelemişlerdir. Çalışmanın örneklemini Gaziantep Üniversitesi'nde eğitim göre 369 yabancı uyruklu ve 369 Türk öğrenci olmak üzere toplam 738 öğrenci oluşturmuştur. Araştırmanın sonucunda öğrencilerin üst-bilişsel ve motivasyonel kültürel zekânın yaşam doyumlarını anlamlı ve pozitif yönde etkilediği tespit edilmiştir. Çalışkan vd. (2015) çalışmalarında 160 yönetici üzerinde yaptıkları araştırmada kültürel zekâ sinizm ilişkisinin incelemişlerdir. Araştırma sonucunda yöneticinin algılanan kültürel zekâsındaki artışın, algılanan farklılık ikliminin ara değişken rolü yardımıyla örgütsel sinizmi düşürdüğü ortaya konulmuştur. Çakan vd., (2016) tarafindan tıp fakültesi öğrencileri üzerinde yapılan bir diğer araştırmada ise damgalanmanın kültürel zekâ ile ilişsisinin araştırılması amaçlanmıştır. Bu amaç çerçevesinde çalışmanın örneklemini Çalışmaya 1. Sinıftan 65, 4. Sinıfta 68 ve 6. sinıftan 112 olmak üzere toplam 245 tıp fakültesi öğrencisi oluşturmaktadır. Araştırmanın sonuçları öğrencilerin kendini damgalama ile kültürel zekâ arasında negatif yönde anlamlı ilişki ortaya çıkmıştır. Ergün ve Güzel (2017) eğitim sektöründe öğrenciler üzerine yapılan bir diğer çalışmada üniversitede eğitim gören kız öğrencilerin kültürel zekâ düzeyleri ile olumsuz otomatik düşünceler arasındaki ilişkiyi incelemişlerdir. Kız öğrenci apartlarında 
kalan 400 kız üniversite öğrencisi üzerinde yaptıkları araştırma sonucunda olumsuz otomatik düşüncenin kültürel zekâyı etkilediğini bulmuşlardır. Ayrıca kitap okumanın da üst bilişsel zekâya anlamlı ve olumlu etkisini tespit etmişlerdir. Şimşek ve Öztürk (2018), hastane yöneticileri üzerinde yaptıkları çalışmada kültürel zekâ ve dönüşümsel liderlik arasındaki ilişkiyi incelemiştir. Araştırmanın evrenini Adana ve Mersin'de dört farklı özel hastanede görev yapan 65 yönetici oluşturmaktadır. Araştırmada elde edilen sonuçlar, üst bilişsel kültürel zekâ ve bilişsel kültürel zekâ faktörlerin dönüşümsel liderlik tarzı arasında pozitif güçlü bir ilişkinin olduğunu ortaya koymuştur. Uludağ ve Deveci (2018) hemşirelik öğrencileri üzerinde yaptıkları çalışmada öğrencilerin kültürel zekâ düzeylerini ölçmeyi amaçlamışlardır. Araştırmanın örneklemi Gümüşhane Üniversitesi Sağlık Bilimleri Fakültesi Hemşirelik Bölümü'nde eğitim gören 274 öğrenci oluşturmaktadır. Araştırmadan elde edilen sonuçlar demografik özellikler açısından incelendiğinde kültürel zekâ düzeylerinin cinsiyete göre anlamlı bir farklılık gösterdiği ve erkek öğrencilerin kültürel zekâlarının daha yüksek olduğu bulunmuştur. Abaslı ve Polat (2019) Ankara'da faaliyet gösteren 3 farklı devlet üniversitesinde eğitim gören 337 yerli ve yabancı öğrenci üzerinde yaptıkları araştırmada demografik özelliklerle kültürel zekâ düzeyleri açısından farklılık olup olmadığını incelemişlerdir. Bu çalışma sonucunda öğrencilerin kültürel zekâ algı düzeyleri yaş, eğitim durumu ve uyruk değişkenlerine göre farklılaşmamakta, cinsiyet değişkenine göre ise farklılaşmaktadır.

Yazın incelendiğinde sosyal zekâ ile ilgili hem iş yaşamına yönelik hem de öğrenciler üzerine çalışmalara rastlanmaktadır. Yerli yazına bakıldığında Hançer ve Tanrısevdi (2003) çalışmalarında sosyal zekâ ile olan sosyal davranış ve performans arasındaki ilişkileri teorik olarak incelemişlerdir. Çalışma sonucunda sosyal zekânın yöneticilerin kural ya da normları uygulamasını kolaylaştırdığı ve örgüt içinde güvenin artmasını sağladığı ifade edilmiştir. Doğan vd. (2009) çalışmalarında Sakarya Üniversitesi öğrencilerinin sosyal zekâ düzeylerini incelemişlerdir. Çalışmanın örneklemini 286 kadın ve 226 erkek öğrenci oluşturmuştur. Araştırma sonucunda öğrencilerin sosyal zekâ düzeylerinin cinsiyete göre farklılık göstermediği tespit edilmiştir. Buna rağmen sosyal bilimler alanında eğitim gören öğrencilerin fen alanındaki öğrencilere göre sosyal zekâ düzeylerinin önemli derecede yüksek olduğu bulunmuştur. Ülker (2016) ise, yaptığ1 araştırmada meslek yüksekokulu ögrencilerinin sosyal zekâ ve iletişim becerilerinin farklı değişkenler açısından incelenmesini amaçlamıştır. Araştırmanın örneklemini İstanbul Nişantaşı Üniversitesi'nde değişik ön lisans programlarında eğitim gören 153 erkek ve 147 kız olmak üzere toplam 300 öğrenci oluşturmaktadır. Araştırma sonucunda sosyal zekânın sosyal farkındalık alt boyutundan alınan puanların cinsiyete göre farklılaştığı görülmüştür. Bu kapsamda kadınların erkeklere göre daha fazla sosyal farkındalığa sahip oldukları belirlenmiştir. Bununla birlikte meslek yüksekokulu öğrencilerinin sosyal zekâ puanları ile iletişim becerileri puanları arasında da pozitif yönlü anlamlı ilişki olduğu belirlenmiştir. Abdullayeva (2018) yaptığı çalışmada üstün zekâlı çocukların sosyal zekâ düzeylerinin normal 
gelişim gösteren çocuklara göre karşılaştırmıştır. Araştırmanın örneklemini İstanbul ilinde eğitim almakta olan 12-14 yaş aralığında çocuklar oluşturmaktadır. Çalışma sonucunda üstün zekâlı çocukların sosyal zekâ düzeylerinin normal gelişim gösteren çocuklara göre anlamlı şekilde yüksek olduğu bulunmuştur.

Sosyal ve kültürel zekânın kuramsal alt yapısı incelendiğinde ise, hem sosyal hem de kültürel zekânın diğer bireylerle etkileşime girme yeteneği konusunda insanlar arasında görülen bireysel farklılıkları açıklamak amacıyla öne sürülen zekâ alanları olduğu ifade edilmektedir (İlhan ve Çetin, 2014a). Bu iki kavramın ilişkisi üzerine yapılan sınırlı sayıdaki çalışmada ise farklı düşünceler ifade edilmektedir. $\mathrm{Bu}$ kapsamda bazı çalışmalarda sosyal ve kültürel zekâ ilişkisi üzerine yazına bakıldığında ise kültürel zekâ, sosyal zekâdan ayrı bir yapı olarak ele alınmaktadır (Brislin vd., 2006). Diğer yandan, zaman zaman ilgili yazında kültürel zekânın diğer zekâ türlerinden farklı olmadığı ve yeni bir yönetim modası olduğu da ileri sürülmektedir (Şahin vd., 2012). Öyle ki, bazı araştırmacılara göre, sosyal zekânın kültürel zekâyı içine alan bir zekâ türüdür (Crowne, 2009). Bu araştırmacılar, kültürel zekânın dinamik olduğunu, sürekli olarak öğrenmeyi içerdiğini ve sosyal durumlardan etkilendiği ifade etmektedirler (Thomas vd, 2008). Aslında sosyal farkındalık becerileri kişinin kültürel ipuçlarını toplamasına izin verdiğinden hem sosyal zekâ hem de kültürel birbirine yardımcı olmaktadır (Crowne, 2009). Sosyal zekâ ile kültürel zekâ ilişkisine ilişkin teorik çerçeve Şekil 1'de görülebilmektedir.

Şekil 1: Sosyal Zekâ ve Kültürel Zekâ İlişkisine Yönelik Teorik Model

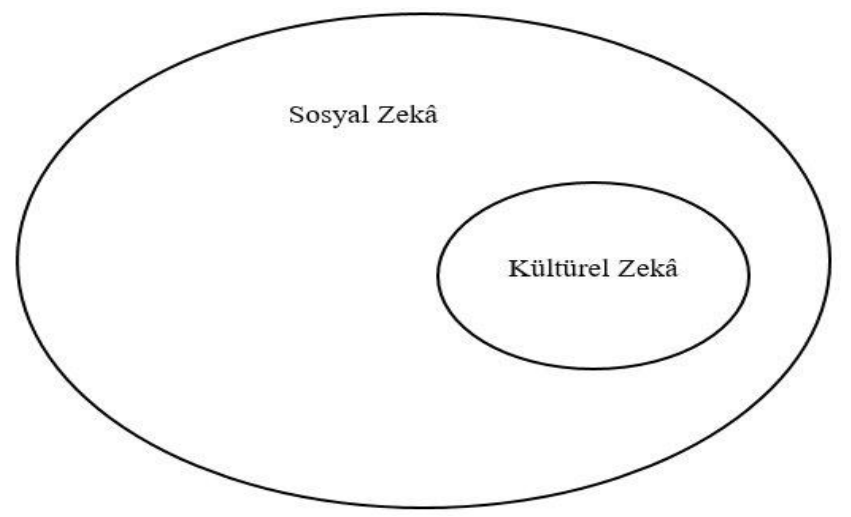

Yazındaki çalışmalara ve yapılan tüm açıklamalara bakıldığında, özellikle çalışma ortamlarında kültürel zekânın çok kültürlü ortamlara uyum sağlamaya (Ward ve Fischer, 2008) ve böylelikle performansın artmasına olumlu yönde etki ettiği ifade edilebilir (Oolders vd., 2008). Bununla birlikte öğrencilerin demografik özellikleri ile kültürel zekâ ilişkisi fazlaca araştırılan bir hususu olarak göze çarpmaktadır. Fakat öğrencilerin akademik başarısının üzerinde kültürel zekâ ve sosyal zekâlarının etkisi üzerinde çok durulmadığı görülmektedir. Aslında kültürel zekâ sosyal zekânın bir alt boyutu olarak değerlendirildiğinde ve sosyal zekânın performans üzerine etkisinde kültürel zekânın düzenleyici bir etkisinin olduğundan bahsetmek daha doğru olacaktır. Bu bağlamda araştırmada sosyal zekânın yabanc1 
uyruklu öğrencilerin akademik performansı üzerindeki etkisinde kültürel zekânın düzenleyici rolü ele alınacaktır. Bu kapsamda araştırmaya ilişkin geliştirilen araştırma modeli Şekil 2'de görülebilmektedir.

Şekil 2: Araştırmanın Kavramsal Modeli

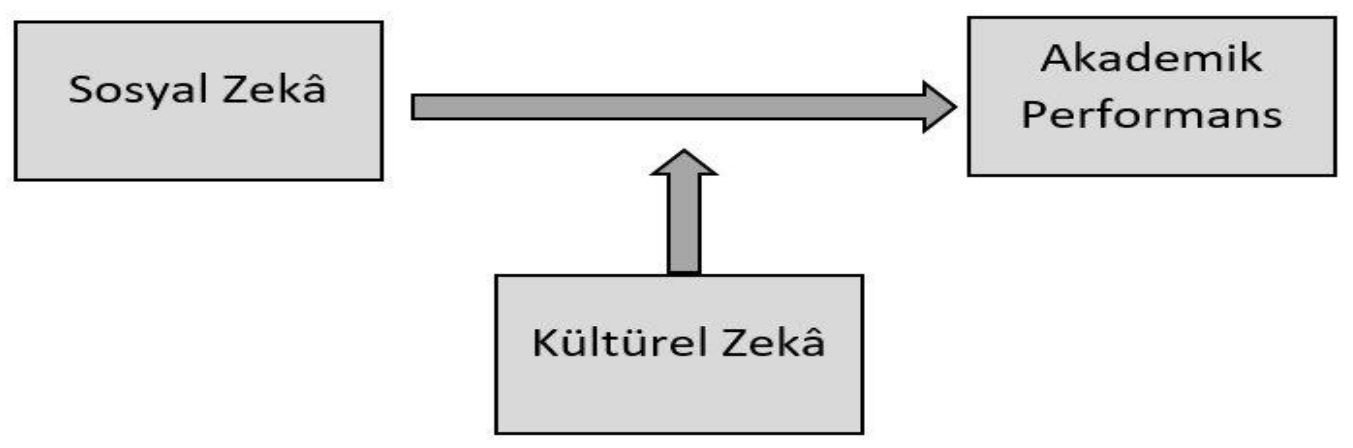

Yazın ve araştırmanın amacı dikkate alınarak geliştirilen araştırma hipotezleri ise aşağıda görüldüğü gibidir;

$\boldsymbol{H}_{1}$ : Sosyal zekâ öğrencilerin akademik performansını etkilemektedir.

$\boldsymbol{H}_{2}$ : Kültürel zekâ öğrencilerin akademik performansını etkilemektedir.

$H_{3}$ : Sosyal zekânın akademik performans üzerine etkisinde kültürel zekânın düzenleyici rolü bulunmaktadır.

\section{Araştırma Yöntemi}

\subsection{Evren ve Örneklem}

Araştırmanın evrenini Yüksek Öğretim Kurumları (YÖK) İstatistiklerine göre Türkiye'nin en çok yabancı uyruklu öğrenci sayısına sahip üniversitelerinden bir tanesi olan Kastamonu Üniversitesi'nde 2018-2019 eğitim öğretim yılında kayıtlı yabancı uyruklu öğrenciler oluşturmaktadır. Bu kapsamda 2019 yılı Şubat ayı itibariyle Kastamonu Üniversitesi verilerine göre 969 k1z ve 3060 olmak üzere toplam 4029 milletlerarası öğrenci bulunmaktadır. Söz konusu evren içerisinde basit tesadüfi örnekleme yönetimi ile seçilen 351 öğrenci oluşturan anketi doldurmuştur. Bunlardan 22 tanesi verileri eksik girdiği tespit edilmiş ve son haliyle anketi dolduran 329 öğrenci analize dâhil edilmiştir. Bu bağlamda çalışmanın örneklemini 329 adet milletlerarası öğrenci oluşturmaktadır.

\subsection{Veri Toplama Aracı}

Çalışmada veriler toplanırken anket yöntemi kullanılmıştır. Kullanılan anketlerde sosyal zekâ düzeyini ölçek için Silvera vd. (2001) tarafindan geliştirilerek Doğan ve Çetin (2009) tarafından Türkçeye uyarlanan ve 20 sorunun yer aldığı Tromsö Sosyal Zekâ Ölçeği kullanılmıştır. Sosyal zekâ ölçeği sosyal bilgi süreci, sosyal beceri ve sosyal farkındalık olmak üzere 3 alt boyuttan oluşmaktadır. Kültürel zekâ düzeyini ölçmek için ise Ang vd. (2007) tarafından geliştirilerek İlhan ve Çetin (2014b) tarafından Türkçeye uyarlanan ve 21 sorudan oluşan kültürel zekâ ölçeği 
kullanılmıştır. Kültürel zekâ üst bilişsel, bilişsel, motivasyonel ve davranışsal olmak üzere 4 alt boyuttan oluşmaktadır. Akademik ortalamaları ölçmek için ise öğrencilerden demografik bilgiler kısmında genel ağırlıklı not ortalamalarını yazmaları istenmiştir. Kullanılan ölçekler farklı boyutlardan oluşmasına rağmen analizler yapılırken ölçekler yazındaki bazı çalışmalarda olduğu gibi (örn; Çalışkan, 2015; Abdullayeva, 2018, ) toplu olarak kullanılmıştır.

\subsection{Değişkenler ve Analiz Yöntemi}

Çalışmada kullanılacak değişkenlerden sosyal zekâ araştırmanın bağımsız değişkenidir. Araştırmanın bağımlı değişkeni ise öğrencilerin performansını gösteren akademik ortalamalarıdır. Çalışmada ele alınacak düzenleyici değişken ise kültürel zekâ olarak ifade edilmektedir. Çalışmada elde edilen verileri ölçmek için öncelikle doğrulayıcı faktör analizleri gerçekleştirilmiştir. Doğrulayıcı faktör analizi yapılırken ölçekler bir bütün olarak kullanılacağından dolayı ikinci düzey DFA yapılacaktır. Doğrulayıcı faktör analizlerinin ardından araştırma hipotezlerini test etmek amaciyla regresyon analizi gerçekleştirilmiştir.

\section{Bulgular}

Araştırma bulguları çerçevesinde öncelikle araştırmaya katılan yabancı uyruklu öğrencilere ilişkin tanımlayıcı bulgulara değinilmiştir. Tanımlayıcı bulgular Tablo 1 'de görülebilmektedir.

Tablo 1 incelendiğinde araştırmaya katılan öğrencilerin çoğunluğunun $(\% 55,9)$ erkek olduğu görülmektedir. Öğrenim durumlarına bakıldığında ise çoğunun (\% 36,8) 4. sınıf ve üzerinde eğitim alan öğrenciler olduğu tespit edilmiştir. Bölüm açısından bakıldığında katılım gösteren öğrenciler çoğunlukla işletme (\% 37,7) ve iktisat $(\%$ 26,1) bölümü öğrencileri olmuştur. Yabanci uyruklu bu öğrencilerin uyruklarına göre dağılımına bakıldığında ise en çok katılım $(\% 39,5)$ fakülte bünyesinde çoğunluğu oluşturan Azerbaycanlı öğrencilerdendir. Onları Kırgızistanlı öğrenciler (\% 29,5) takip etmektedir. Ayrıca diğer kategorisi içerinde Afganistan, Çad, Irak, Gine Bissau gibi ülke öğrencileri de yer almaktadır. Bu sayede farklı milletlere mensup öğrencilerin katılımı söz konusudur.

Katılımcılara ait tanımlayıcı istatistiklerin ardından araştırmada kullanılan ölçeklere ilişkin DFA analizleri gerçekleştirilmiştir. Araştırma kapsamında öncelikle birinci düzey DFA gerçekleştirilmiştir. Birinci düzey DFA sonucunda sosyal zekâ ölçeğinin uyum iyiliği değerlerini yakaladığı görülmüştür. Kültürel zekâ için yapılan birinci düzey DFA sonucunda da uyum iyiliği değerlerinin yakalandığı tespit edilmiştir. Sonrasında yapılan ikinci düzey DFA sonuçları ise her iki ölçek için de birinci düzey DFA sonuçları ile benzeşmektedir. Bununla birlikte çalışmada kullanılacak ölçekler bir bütün olarak ele alınacağından dolayı ikinci düzey DFA analizlerine ilişkin bulgulara yer verilmiştir. Şekil 3'te sosyal zekâ ölçeğine ilişkin DFA bulguları görülebilmektedir. 
Tablo 1: Tanımlayıcı Bulgular

\begin{tabular}{|c|c|c|c|}
\hline Değişkenler & Kategori & Frekans (n) & Yüzde (\%) \\
\hline \multirow{3}{*}{ Cinsiyet } & Erkek & 184 & 55,9 \\
\cline { 2 - 4 } & Kadın & 145 & 44,1 \\
\hline \multirow{4}{*}{ Sınıf } & Birinci Sınıf & 34 & 10,3 \\
\cline { 2 - 4 } & İkinci Sınıf & 77 & 23,4 \\
\cline { 2 - 4 } & Üçüncü Sınıf & 97 & 29,5 \\
\cline { 2 - 4 } & 4. ve üstü Sınıf & 121 & 36,8 \\
\hline \multirow{4}{*}{ Uyruk } & Azerbaycan & 130 & 39,5 \\
\cline { 2 - 4 } & Kırgızistan & 97 & 29,5 \\
\cline { 2 - 4 } & Kazakistan & 30 & 9,1 \\
\cline { 2 - 4 } & Diğer & 72 & 21,9 \\
\hline \multirow{4}{*}{ Bölüm } & İktisat & 86 & 26,1 \\
\cline { 2 - 4 } & SBKY & 47 & 14,3 \\
\cline { 2 - 4 } & İşletme & 124 & 37,7 \\
\cline { 2 - 4 } & Diğer & 72 & 21,9 \\
\hline
\end{tabular}

Şekil 3: Sosyal Zekâ Ölçeğine İlişkin DFA Bulguları

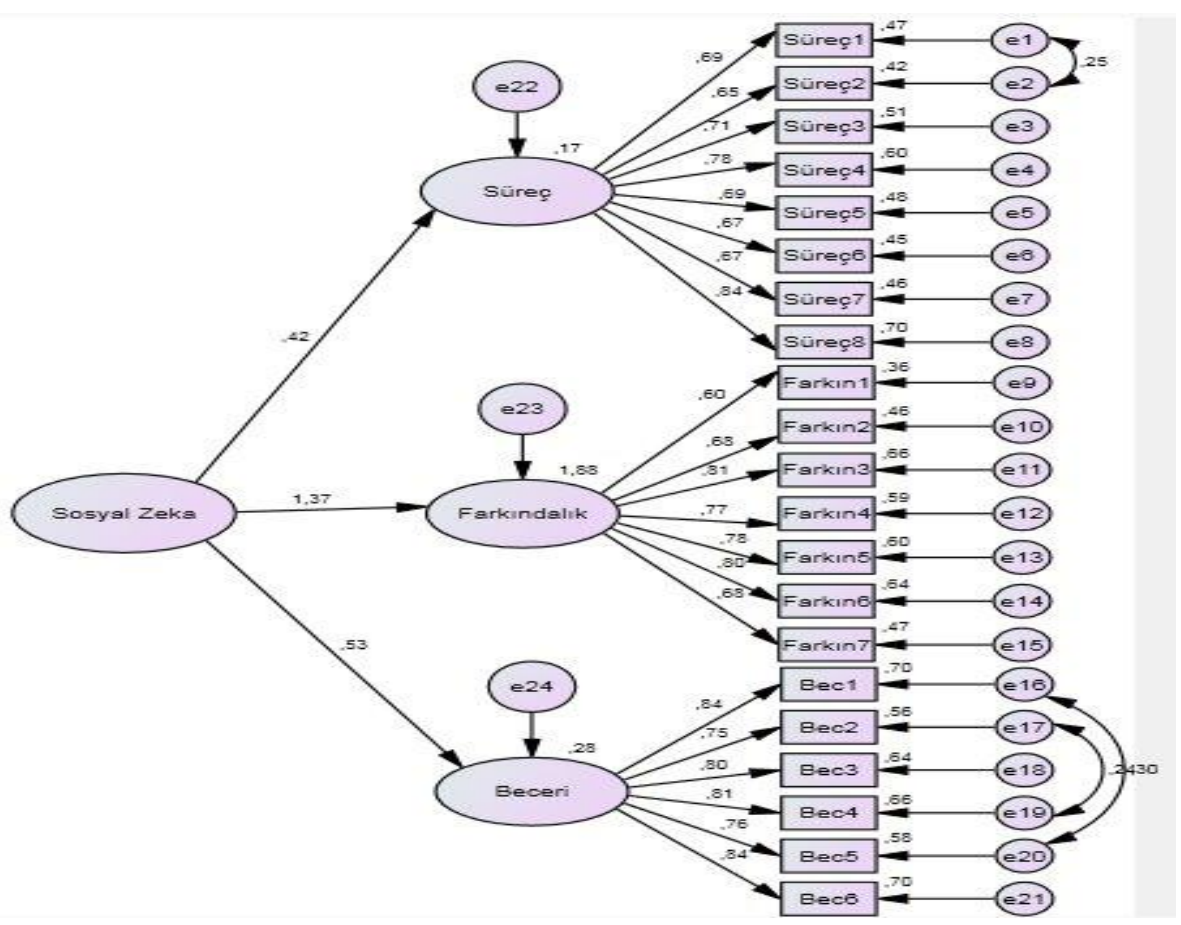


Şekil 3'te görünen faktör analizi sonucu ortaya çıkan uyum iyiliği değerlerinin de kabul edilebilir sınırlar içerinde olduğu tespit edilmiştir. Bu bağlamda sosyal zekâ ölçeği sosyal bilgi süreci, sosyal beceri ve sosyal farkındalık alt boyutlarından oluşan bir ölçektir. Tablo 2'de söz konusu uyum iyiliği değerlerine ait sınır değerler ve araştırmanın uyum iyiliği bulguları özetlenmiştir. Kültürel zekâ ölçeğine ilişkin DFA bulguları ise Şekil 4'te görülebilmektedir.

Tablo 2: Sosyal Zekâ Ölçeği için Uyum İyiliği Değerleri

\begin{tabular}{|c|c|c|c|}
\hline Uyum Ölçütleri & Normal Ölçüt & Kabul Edilebilir Ölçüt & Elde Edilen Ölçütler \\
\hline X2/df & $\leq 2$ & $\leq 5$ & 2,35 \\
\hline RMSEA & $\leq 0,05$ & $\leq 0,08$ & 0,06 \\
\hline GFI & $\geq 0,95$ & $\geq 0,90$ & 0,89 \\
\hline CFI & $\geq 0,95$ & $\geq 0,90$ & 0,94 \\
\hline NFI & $\geq 0,95$ & $\geq 0,90$ & 0,90 \\
\hline RFI & $\geq 0,90$ & $\geq 0,85$ & 0,87 \\
\hline AGFI & $\geq 0,90$ & $\geq 0,85$ & 0,86 \\
\hline TLI & $\geq 0,95$ & $\geq 0,90$ & 0,93 \\
\hline
\end{tabular}

Şekil 4: Kültürel Zekâ Ölçeğine İlişkin DFA Bulguları

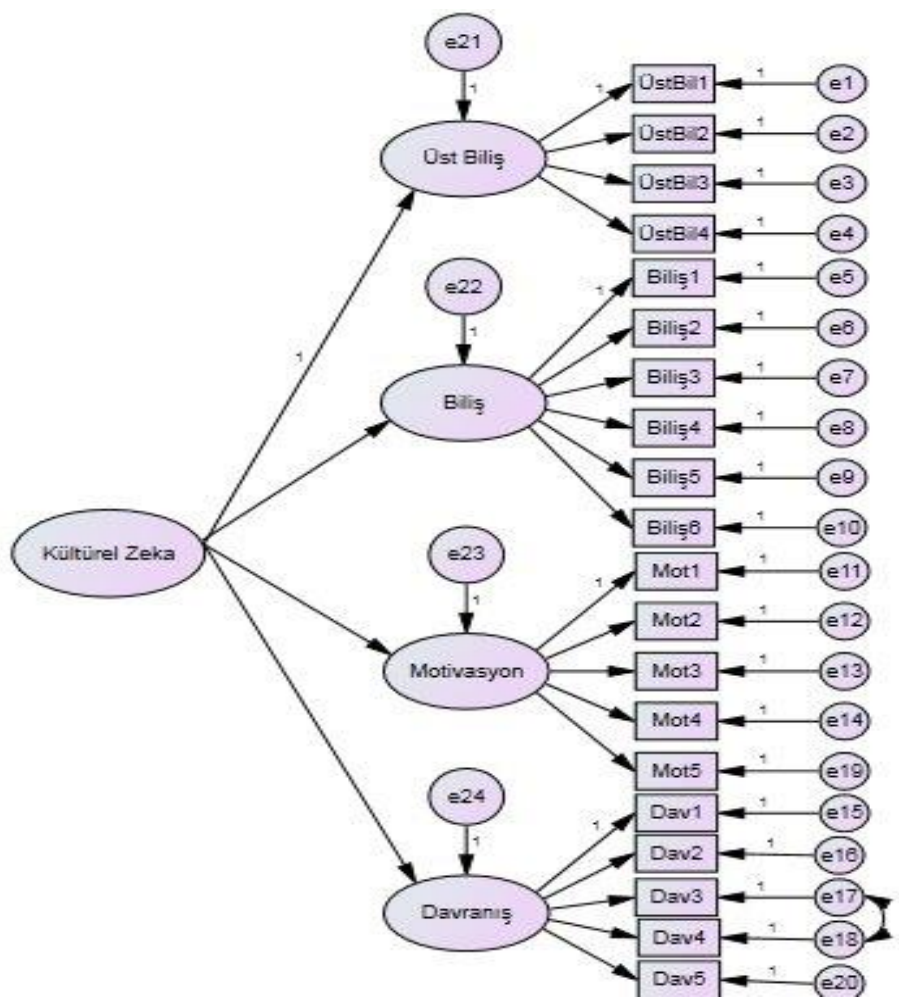

Şekil 4'te görünen faktör analizi sonucu ortaya çıkan uyum iyiliği değerlerinin de kabul edilebilir sınırlar içerinde olduğu tespit edilmiştir. Bu bağlamda kültürel zekâ ölçeği üst biliş, biliş, motivasyon ve davranış alt boyutlarından oluşan bir ölçektir. 
Tablo 3'te söz konusu uyum iyiliğine ait sınır değerler ve araştırmanın uyum iyiliği bulguları özetlenmiştir.

Tablo 3: Kültürel Zekâ Ölçeği için Uyum İyiliği Değerleri

\begin{tabular}{|c|c|c|c|}
\hline Uyum Ölçütleri & Normal Ölçüt & Kabul Edilebilir Ölçüt & Elde Edilen Ölçütler \\
\hline X2/df & $\leq 2$ & $\leq 5$ & 2,84 \\
\hline RMSEA & $\leq 0,05$ & $\leq 0,08$ & 0,07 \\
\hline GFI & $\geq 0,95$ & $\geq 0,90$ & 0,88 \\
\hline CFI & $\geq 0,95$ & $\geq 0,90$ & 0,95 \\
\hline NFI & $\geq 0,95$ & $\geq 0,90$ & 0,93 \\
\hline RFI & $\geq 0,90$ & $\geq 0,85$ & 0,91 \\
\hline AGFI & $\geq 0,90$ & $\geq 0,85$ & 0,85 \\
\hline TLI & $\geq 0,95$ & $\geq 0,90$ & 0,94 \\
\hline
\end{tabular}

Faktör analizlerinin ardından çalışmada ileri sürülen hipotezlerin testi için regresyon analizleri gerçekleştirilecektir. Fakat öncesinde araştırmada ele alınan bağımsız değişken, bağımlı değişken ve düzenleyici değişkene ilişkin tanımlayıcı bulgulara yer vermek gerekmektedir. Değişkenlere ilişkin tanımlayıcı bulgular Tablo 4'te sunulmuştur.

Tablo 4: Değişkenlere İlişkin Tanımlayıcı Bulgular

\begin{tabular}{|c|c|c|c|c|}
\hline Değişkenler & Ortalama & Standart Sapma & Çarpıklık & Basıklık \\
\hline Sosyal Zekâ & 2,31 &, 7215 &, 218 &, 105 \\
\hline Kültürel Zekâa & 2,04 &, 9085 &, 465 &,- 960 \\
\hline Akademik Performans & 2,14 &, 5102 &, 576 &, 103 \\
\hline
\end{tabular}

Tablo 4 incelendiğinde araştırmaya katılan öğrencilerin sosyal zekâ düzeyleri $(2,31)$ kültürel zekâ düzeylerinden $(2,04)$ daha fazladır. Akademik performansları ise ortalama 2,14 olarak tespit edilmiştir. Basıklık ve çarpıklık değerleri ise özellikle sosyal bilimlerde verilerin normal dağılıma uygunluğunu ortaya koymak için önemli bir değerdir. Bu noktada yazında farklı görüşler söz konusudur. George ve Mallery'e (2010) göre çarpıklık ve basıklık değerlerinin - 2 ile +2 aralığında yer alması verilerin normal dağıldığını göstermektedir. Ayrıca Liu vd. (2009), çarpıklık ve basıklık değerlerinin \%5 güven aralığı için istatistik değerinin - 2.58 ile $+2,58$ aralığında, \%1 güven aralığı için de istatistik değer aralığının -1.96 ile $+1,96$ aralığında olmasının beklendiğini ifade etmişlerdir. Araştırmada çıkan basıklık ve çarpıklık değerlerinin bu araştırmalarda ifade edilen değerler arasında olduğu görülmektedir. $\mathrm{Bu}$ bağlamda verilerin normal dağıldığını ifade etmek doğru olacaktır. Verilere ilişkin tanımlayıcı istatistiklerin ardından hipotez testlerine geçilmiştir. $\mathrm{Bu}$ kapsamda ilk adımda bağımsız değişkenin bağımlı değişken üzerindeki etkisine bakılmıştır. İkinci adımda bağımsız değişkenler birlikte düzenleyici değişken modele dahil edilerek her ikisinin bağımlı değişken üzerindeki etkisi incelenmiş̧tir. Son adımda ise bağımsız, düzenleyici değiş̧ken ile birlikte bağımsız ve düzenleyici değişkenin çarpımı sonucu elde edilen etkileşim 
değişkeni modele atılarak düzenleyici etkinin var olup olmadığı tespit edilmiştir. Bu bağlamda yapılan analiz sonuçları Tablo 5 'te özetlenmektedir.

Düzenleyici etki modelinin analizi neticesinde kültürel zekânın, sosyal zekânın ve bu iki değişkenin çarpımından oluşan etkileşim değişkeninin akademik performansı anlamlı olarak etkilediği bulgusuna ulaşılmıştır. Bu bulgu sosyal zekânın akademik performans üzerindeki etkisinde kültürel zekânın düzenleyici rolü bulunduğunu göstermektedir. Bununla birlikte düşük ve yüksek kültürel zekânın düzenleyici etkisini gösteren grafik Şekil 5 'te sunulmuştur. Söz konusu grafik Jeremy Dawson tarafından geliştirilen Excell formatı kullanılarak hazırlanmıştır. Grafiğgi oluşturabilmek için standardize edilmemiş beta katsayısı tahmin değerleri kullanılmıştır.

Tablo 5: Regresyon Analiz Bulguları

\begin{tabular}{|c|c|c|c|c|c|c|c|}
\hline \multicolumn{5}{|c|}{ Model Özeti } & \multicolumn{3}{|c|}{ Katsayılar } \\
\hline \multicolumn{8}{|c|}{ Bağımlı Değişken: Akademik Performans } \\
\hline \multirow{3}{*}{$\begin{array}{c}1 . \\
\text { Adım }\end{array}$} & $\mathbf{R}^{2}$ & Düz & $\mathbf{F}$ & $\mathbf{P}$ & $\mathbf{t}$ & $\boldsymbol{\beta}$ & $\mathbf{p}$ \\
\hline & , 183 & ,181 & 73,3 & ,000 & \multicolumn{3}{|c|}{ Katsayılar } \\
\hline & \multicolumn{4}{|c|}{ Sosyal Zekâ } & 8,567 & ,428 & ,000 \\
\hline \multirow{4}{*}{$\begin{array}{c}2 . \\
\text { Adım }\end{array}$} & $\mathbf{R}^{2}$ & Düz & $\mathbf{F}$ & $\mathbf{P}$ & $\mathbf{t}$ & $\boldsymbol{\beta}$ & $\mathbf{p}$ \\
\hline & ,202 & 197 & 41,1 & ,000 & \multicolumn{3}{|c|}{ Katsayılar } \\
\hline & \multicolumn{4}{|c|}{ Sosyal Zekâ } & 6,756 & ,367 &, 000 \\
\hline & \multicolumn{4}{|c|}{ Kültürel Zekâ } & 2,726 & , 148 & 007 \\
\hline \multirow{5}{*}{$\begin{array}{c}3 . \\
\text { Adım }\end{array}$} & $\mathbf{R}^{2}$ & Düz & $\mathbf{F}$ & $\mathbf{P}$ & $\mathbf{t}$ & $\boldsymbol{\beta}$ & $\mathbf{p}$ \\
\hline & 227 & 219 & 31,7 & ,000 & \multicolumn{3}{|c|}{ Katsayılar } \\
\hline & \multicolumn{4}{|c|}{ Sosyal Zekâ } & 4,536 & ,275 &, 000 \\
\hline & \multicolumn{4}{|c|}{ Kültürel Zekâ } & 2,298 &, 124 &, 022 \\
\hline & \multicolumn{4}{|c|}{ Sosyal Zekâ X Kültürel } & 3,248 & , 190 & ,001 \\
\hline \multicolumn{5}{|c|}{ 1. Adım: $\mathrm{R} 2=, 183 \quad$ Düz. $\mathrm{R} 2=$, } & \multicolumn{3}{|c|}{ R2 Değişimim=, 181} \\
\hline \multicolumn{3}{|c|}{ 2. Adım: $\mathrm{R}^{2}=, 202$} & \multicolumn{3}{|c|}{ Düz. $\mathrm{R}^{2}=, 197$} & \multicolumn{2}{|c|}{$\mathrm{R}^{2}$ Değişim $=, 016$} \\
\hline \multicolumn{3}{|c|}{ 3. Adım: $\mathrm{R}^{2}=, 227$} & \multicolumn{2}{|c|}{ Düz. $\mathrm{R}^{2}=, 219$} & \multicolumn{3}{|c|}{$\mathrm{R}^{2}$ Değişisim $=, 022$} \\
\hline
\end{tabular}

Şekil 5 incelendiğinde akademik performansın en yüksek olduğu nokta, sosyal ve kültürel zekâ düzeyinin yüksek olduğu durumdur. Akademik performansın en düşük olduğu nokta ise, sosyal ve kültürel zekâ düzeyinin düşük olduğu durumdur. Sosyal zekânın en düşük olduğu noktada, kültürel zekâ düzeyindeki değişim akademik performans üzerinde değişiklik yaratmazken, sosyal zekâ güçlendikçe kültürel zekânın gücü sosyal zekânın performansa etkisini güçlendirmektedir. Kısacası kültürel zekâ, sosyal zekâ akademik performans arasındaki ilişkiyi pozitif olarak moderate etmektedir. Yani daha yüksek kültürel zekâya sahip olmak sosyal zekânın akademik performans üzerindeki etkisini arttırmakta, sosyal zekâyı akademik performans için daha verimli kılmaktadır. 
Şekil 5: Kültürel Zekânın Sosyal Zekâ Akademik Performans İlişkindeki Düzenleyici Etkisi

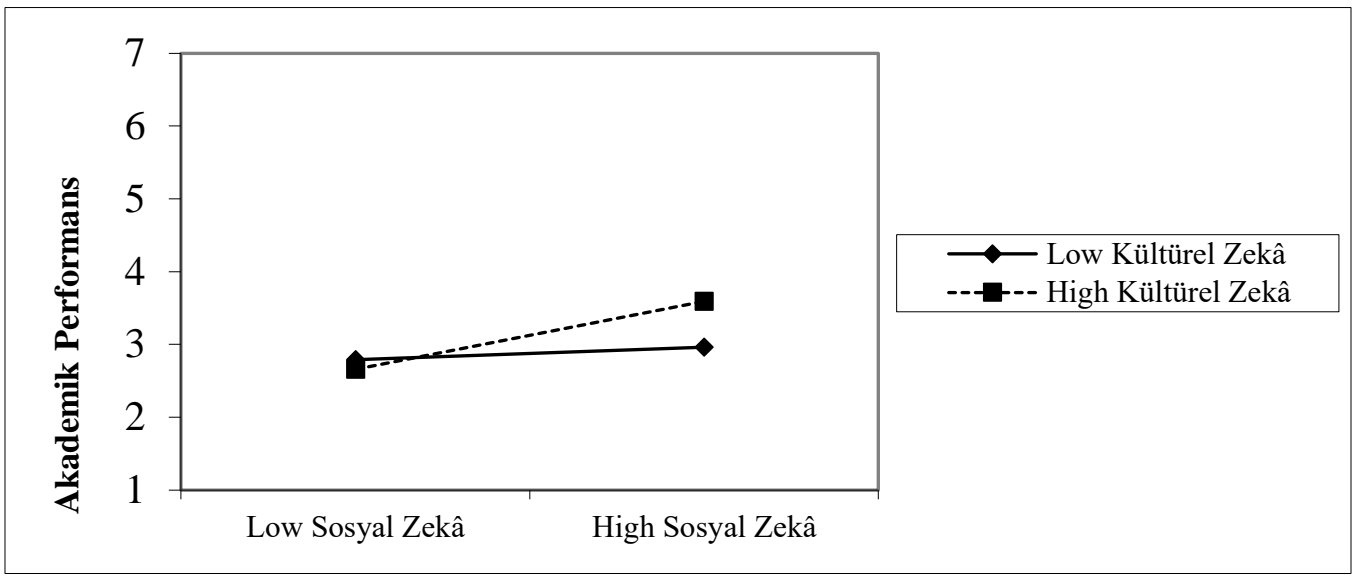

\section{Sonuç ve Öneriler}

Özellikle küreselleşmenin yarattığı etki ile birlikte mesafelerin kısalması farklı kültürlere sahip öğrencilerin transferinin kolaylaşmasına neden olmuştur. Farklı kültürlerle tanışan kişiler öncelikle yıllardır bulundukları kültürden daha farklı bir kültür içerinde farklı yöntemler ve bakış açıları geliştirmelidir. Özellikle öğrenciler yurt dışına ilk çıktıklarında kültür şoku olarak bilinen ve uzunluğu kişiden kişiye değişen bir süreç yaşamaktadırlar. Çünkü gidilen ülkedeki insanların davranış biçimleri, yemek alışkanlıkları, temizlik anlayışları, trafik, komşuluk ve arkadaşlık ilişkileri, iletişim tarzları gibi şeylerin yabancı gelmesi söz konusudur. Bu noktada bazen karamsarlık ortaya çıkabilir ve bu durum bir hayal kırıklığına da neden olabilir. Bu durum her ne kadar geçici olsa da, bu hayal kırklığı akademik performansı da olumsuz yönde etkileyebilir. Bu noktada özellikle sosyal yönden güçlü insanların tercih ettiği farklı kültürel ortamlarda başarılı olabilmek için kültürel zekânın önemli bir rolü olduğu düşünülmektedir. Bu bağlamda sosyal zekânın akademik performans üzerindeki etkisinde kültürel zekânın düzenleyici rolünün incelendiği bu çalışmada sosyal ve kültürel zekânın akademik performansı olumlu yönde etkilediği sonucuna ulaşılmıştır. Bununla birlikte sosyal zekânın akademik performans üzerindeki etkisinde kültürel zekânın düzenleyici bir rol üstlendiği sonucuna varılmıştır.

$\mathrm{Bu}$ bağlamda öğrencilerin farklı kültürlere giderken kültürel değişikliklerden kaynaklanan belirsizlikleri azaltmak için kültürel farklılıkların bilincinde olmaları ve kendilerinden farklı insanlarla bağlantı kurma becerilerini geliştirmeleri önem arz etmektedir. Yani kültürel zekâ kültürel şartlara etkin bir şekilde uyum sağlamaya neden olan bir gösterge olarak ifade edilebilir. Öyle ki, birçok çalışmada kültürel zekânın kültürler arası bireysel etkileşimdeki etkinliği açıklamak için gerekli olduğu vurgulanmaktadır (örn, Earley, 2002; Earley ve Ang, 2003). İletişimin insanlarla fikir alışverişi yapmayı sağlayan, insan ilişkilerini güçlendiren ve insanları birbirine ulaştıran bir araç olduğu düşünüldüğünde günümüzün 
küreselleşen dünyasında sosyal zekânın yanına kültürlerarası bağlamda kültürel zekânın da eklenmesi önemlidir. Aslında yüksek kültürel zekâ seviyesine sahip bir insan yeni bir grubun bütün kültürü yansıtan davranışları ile birlikte bir kişiye ya da gruba özgü olan davranışları ayırt edebilir (Earley ve Mosakowski, 2004).

$\mathrm{Bu}$ sonuçlar çerçevesinde özellikle yükseköğretimin uluslararasılaşması çerçevesinde kültüreler arası yönetim derslerinin eğitim ve öğretim programlarının tasarlanmasında önemli bir yerinin olduğunu söylemek gerekmektedir. Çünkü bu tür dersler kültürlerarası farklılıkları yönetmede kullanılan stratejilerinden biri olan kültürel zekâ kavramını anlamayı sağlayabilir. $\mathrm{Bu}$ çalışma daha geniş örneklemlerde ve sadece Türkiye'ye gelen değil yurt dışına giden öğrenciler üzerinde de yapılarak genişletilebilir. Ayrıca ilerleyen çalışmalarda gelen ve giden öğrencilerin sosyal ve kültürel zekâ düzeyleri ile akademik performansları arasındaki ilişki karşılaştırılarak daha genel yargılara varılabilir.

Tüm bunlarla birlikte üniversitelerin kalite sistemi çalışmalarında da üzerinde durulan uluslararasılaşma faaliyetlerine önem verilmesi ile arttırılması istenilen öğrenci hareketliliği bağlamında öğrencilerin akademik başarılarının kültürel özelliklerden etkilendiği düşünülmektedir. Akademik başarının hem geldikleri ülke hem de eğitim alınan ülke için önemli olduğu açıktır. Bu bağlamda çalışmanın kültürel zeka ve sosyal zeka kavramlarını birlikte ele alarak, akademik başarı üzerindeki etkisini incelemesi literatüre katkısı açısından değerlidir, çünkü bu yöndeki çalışmaların sayısının oldukça az olduğu söylenebilir. Çalışmanın sonuçları, yurtdışına giden ve gelen yabancı öğrenci hareketliliğinin yoğun olduğu ülkemizde bu öğrencilerin akademik performanslarını değerlendirme adına önemlidir. Sosyal ve kültürel zekanın akademik performansı olumlu yönde etkilediği sonucuna ulaşılmıştır. Çalışmanın kısıtı sadece Türkiye'deki yabancı uyruklu öğrenciler üzerinde araştırmanın yapılmış olmasıdır. Çalışmanın genellenebilmesi adına farklı üniversitelerdeki yabancı uyruklu öğrenciler daha sonraki çalışmalara dahil edilebilir. Ancak araştırmanın genişletilerek Türkiye'den yurtdışına giden öğrenciler ile gelen öğrenciler arasında karşılaştırma yapılabilecek düzeye getirilmesi literatüre daha fazla katkı sağlayacaktır.

\section{Kaynakça}

Abaslı, K. ve Polat, Ş. (2019). Öğrencilerin Kültürlerarası Duyarlılık ve Kültürel Zekâya İlişskin Görüşlerinin İncelenmesi, Anemon Muş Alparslan Üniversitesi Sosyal Bilimler Dergisi, 7(1), 193-202.

Abdullayeva, L. (2018). Üstün Zekâlı Çocukların Normal Gelişim Gösteren Çocuklara Göre Sosyal Zekâ Düzeylerinin İncelenmesi, Yüksek Lisans Tezi, İstanbul Aydın Üniversitesi Sosyal Bilimler Enstitüsü.

Alon, I. ve Higgins, J. M. (2005). Global Leadership Success Through Emotional and Cultural Intelligences, Business Horizons, 48, 501-512. 
Ang, S., Van Dyne, L., Koh, C., Ng, K.Y., Templar, K.J., Tay, C., ve Chandrasekar, N.A. (2007). Cultural Intelligence: Its Measurement and Effects on Cultural Judgment and Decision Making, Cultural Adaptation and Task Performance, Management and Organization Review, 3(3), 335-371.

Ang, S. ve Van Dyne, L., (2008). Conceptualization of Cultural Intelligence: Definition, Distinctiveness, and Nomological Network, içinde S. Ang, \& L. Van Dyne, (Ed.), Handbook on Cultural Intelligence: Theory, Measurement and Applications, ss. 3-15. Armonk, NY: M.E. Sharpe.

Barakat, L. L., Lorenz, M. P., Ramsey, J. R. ve Cretoiu, S. L. (2015). Global Managers: An Analysis of The Impact of Cultural Intelligence on Job Satisfaction and Performance, International Journal of Emerging Markets, 10(4), 781-800.

Bezirgan, M., Mercan, N. ve Alamur, B. (2015). Turizm Çalışanlarının Kişilik Özelliklerinin Kültürel Zekâları Üzerindeki Etkisi: Edremit Körfezi Örneği, Organizasyon ve Yönetim Bilimleri Dergisi, 7(1), 16-29.

Brislin, R., Worthley, R. ve Macnab, B. (2006). Cultural Intelligence: Understanding Behaviors That Serve People's Goals, Group \& Organization Management, 31(1), 40-55.

Büyükbeşe, T., ve Yıldız, B. (2016). Kültürel Zekânın Yaşam Doyumu Üzerine Etkisi, Journal of International Social Research, 9(45), 438-449.

Crowne, K. (2008). What Leads to Cultural Intelligence?, Business Horizons, 51, 91-399.

Crowne, K. A. (2009). The relationships among Social Intelligence, Emotional Intelligence and Cultural Intelligence, Organization Management Journal, 6, 148-163.

Çakan, E., Buturak, Ş. V., Özçiçek, G., Koçak, O. M., Rezaki, H. Ö., Özpolat, A. G. Y., ve Oğuztürk, Ö. (2016). Tıp Fakültesi Öğrencilerinde Psikiyatrik Yardım Alma Nedeniyle Kendini Damgalama Hissinin Sosyal Zekâ ve Kültürel Zekâ ile İlişkisi, Journal of Mood Disorders (JMOOD), 6(3), 140-145.

Çalışkan, S. C., Ünal, Z. M., Kalafatoğlu, Y., Üçler, Ç. ve Akün, F. A. (2015). Yöneticilerin Algılanan Kültürel Zekâsı, Çalışanın Farklılık İklimi Algısı, Gelişime Açıklık ve Örgütsel Sinizm Etkileşimi Üzerine Turizm Sektöründe Bir Araştırma, İş ve Insan Dergisi, 2(1), 1-11.

Demirbağ, M. ve Mirza, H. (2000). Factors Affecting International Joint Venture Success: An Empirical Analysis of Foreign-Local Partner Relationships and Performance in Joint Ventures in Turkey, Intemational Business Review, 9, 135.

Dowson, J., http://www.jeremydawson.co.uk/slopes.htm, (Erişim tarihi: 01.04.2019) 
Doğan, T. (2006). Üniversite Öğrencilerinin Sosyal Zekâ Düzeylerinin Depresyon ve Bazı Değişkenlerle İlişkisinin İncelenmesi, Yüksek Lisans Tezi, Sakarya Üniversitesi Sosyal Bilimler Enstitüsü, Sakarya.

Doğan, T., Totan, T. ve Sapmaz, F. (2009). Üniversite Öğrencilerinde Benlik Saygısı Ve Sosyal Zekâ, Sakarya Üniversitesi Eğitim Fakültesi Dergisi, (17), 235-247.

Doğan, T. ve Çetin, B. (2009). Tromso Sosyal Zekâ Ölçeği Türkçe Formunun Faktör Yapısı, Geçerlik ve Güvenirlik Çalışması, Educational Sciences: Theory and Practice, 7(1), 241-268.

Doğutaş, A. (2015). Küreselleşen Dünyada Türk Öğretmen Adaylarının Kültürel Zekâ Seviyeleri, Bartın Üniversitesi Eğitim Fakültesi Dergisi, 4(2), 530-547.

Duff, A. J., Tahbaz, A. ve Chan, C. (2012). The Interactive Effect of Cultural Intelligence and Openness on Task Performance, Research \& Practice in Human Resource Management, 20(1), 1-12.

Earley, P. C. (2002). Redefining Interactions across Cultures and Organizations: Moving Forward with Cultural Intelligence, Research in Oganizational Behavior, 24, 271-299.

Earley, P.C. ve Ang, S. (2003). Cultural Intelligence: Individual Interactions across Cultures, CA: Stanford University Press.

Earley, P.C. ve Mosakowski, E. (2004). Cultural Intelligence, Harvard Business Review, 139-146.

Eisenberg, J., Lee, H. J., Brück, F., Brenner, B., Claes, M. T., Mironski, J. ve Bell, R. (2013). Can Business Schools Make Students Culturally Competent? Effects of Cross-Cultural Management Courses on Cultural Intelligence, Academy of Management Learning \& Education, 12(4), 603-621.

Emre, İ., Söylemez, Ö. ve Yıldırım Kaptanoğlu, A. (2013). Örgütlerde Kültürel Zekâ ve Hastane İşletmelerinde Kültürel Zekâ Düzeyinin Belirlenmesine Yönelik Bir Araştırma, Kafkas Üniversitesi İktisadi ve İdari Bilimler Fakültesi Dergisi, 4(5), 1-18.

Ergün, G. ve Güzel, A. (2017). Üniversite Öğrencilerinin Kültürel Zekâ Düzeylerinin Olumsuz Otomatik Düşünceler ve Bazı Diğer Değişkenlere Göre Değerlendirilmesi, Gümüşhane Üniversitesi Sağlık Bilimleri Dergisi, 6(4), 3043.

Ersoy, A. ve Ehtiyar, R. (2015). Kültürel Farkl1lıkların Yönetiminde Kültürel Zekânın Rolü: Türk ve Yabancı Yöneticiler Üzerine Bir Araştırma, Anatolia: Turizm Araştırmaları Dergisi, 26(1), 42-60.

George, D. ve Mallery, P. (2010). SPSS for Windows Step by Step:A Simple Study Guide and Reference, Boston: Pearson Pub. 
Goleman, D. (2016). Sosyal Zeka - İnsan İlişkilerin Yeni Bilimi, Varlık Yayınları, İstanbul.

Hançer, M. ve Tanrısevdi, A. (2003). Sosyal Zekâ Kavramının Bir Boyutu Olarak Empati ve Performans Üzerine Bir İnceleme, CU Sosyal Bilimler Dergisi, 27(2), 211-225.

Herrmann, E., Call, J., Hernández-Lloreda, M. V., Hare, B. ve Tomasello, M. (2007). Humans Have Evolved Specialized Skills of Social Cognition: The Cultural Intelligence Hypothesis, Science, 317, 1360-1366.

Huff, K. C., Song, P. ve Gresch, E. B. (2014). Cultural Intelligence, Personality, and Cross-Cultural Adjustment: A Study of Expatriates in Japan, International Journal of Intercultural Relations, 38, 151-157.

İlhan Nas, T. (2006). Kültürün Örgütlerdeki Rolü: Benimsenen Teorik Perspektifler ve Yöntem Tartışmalarına İlişkin Kavramsal Bir İnceleme, Atatürk Üniversitesi I.I. B.F. Dergisi, 20, 273-292.

İlhan Nas, T. (2007). Uluslararası Ortak Girişimlerde Mülkiyet Yapısı: Yönetsel Kontrol Düzeyinin ve Kültürel Farklılıkların Etkisi, Akdeniz Üniversitesi I.I.B.F. Dergisi, 7, 122-148.

İlhan, M. ve Çetin, B. (2014a). Sosyal ve Kültürel Zekâ Arasındaki İlişkinin Yapısal Eşitlik Modeli ile İncelenmesi, Turkish Journal of Education, 3(2), 4-15.

İlhan, M. ve Çetin, B. (2014). Kültürel Zekâ Ölçeği'nin Türkçe Formunun Geçerlik ve Güvenirlik Çalışması, Hacettepe Üniversitesi Ĕ̆itim Fakültesi Dergisi, 29(29-2), 94-114.

Jyoti, J. ve Kour, S. (2015). Assessing the Cultural Intelligence and Task Performance Equation: Mediating Role of Cultural Adjustment, Cross Cultural Management, 22(2), 236-258.

Koparan E., İlhan Nas T. ve Okan T. (2016). Ulusal Kültürün Kurumsal Sosyal Sorumluluk Uygulamaları Üzerindeki Etkisi: Gelişmiş ve Gelişmekte Olan Ülkeler Üzerine Bir Araştırma, TiSK Akademi, 11, 352-379.

Lin, Y., Chen, A. S. ve Song, Y. (2012). Does Your Intelligence Help to Survive in a Foreign Jungle? The Effects of Cultural Intelligence and Emotional Intelligence on Cross-cultural Adjustment, International Journal of Intercultural Relations, 36, 541-552.

Liu Y, Li Z, Hayward R, Walker R, ve Jin H (2009). Classification of Airborne LIDAR Intensity Data Using Statistical Analysis and Hough Transform with pplication to Power Line Corridors, İçinde, Proc. 2009 Digital Image Computing: Techniques and Applications, Melbourne, Australia, 462-467. 
Livermore, D. (2011). The Cultural Intelligence Difference-Special eBook Edition: Master the One Skill You Can't Do Without in Today's Global Economy, Amacom

Livermore, D. (2013). Expand Your Borders: Discover Ten Cultural Clusters, East Lansing, MI: Cultural Intelligence Center.

MacNab, B. R. ve Worthley, R. (2012). Individual Characteristics as Predictors of Cultural Intelligence Development: The Relevance of Self-Efficacy, International Journal of Intercultural Relations, 36, 62-71.

Moss, F.A, ve Hunt, T. (1927). Are You Socially Intelllgent?, Scientific American, 137, 108-110.

Oolders, T., Chernyshenko, O. S. ve Stark, S. (2008). Cultural Intelligence as a Mediator of Relationships between Openness to Experience and Adaptive Performance, Handbook of Cultural Intelligence: Theory, Measurement, and Applications, 145-158.

Peterson, B. (2004). Cultural Intelligence: A Guide to Working with People from Other Cultures, Published by Intercultural, A.B.D.

Ramalu, S. S., Rose, R. C., Uli, J. ve Kumar, N. (2012). Cultural Intelligence and Expatriate Performance in Global Assignment: The Mediating Role of Adjustment, International Journal of Business and Society, 13(1), 19-32.

Silvera, D. H., Martinussen, M. ve Dahl, T. I. (2001). The Tromso Social Intelligence Scale, a Self-report Measure of Social Intelligence, Scandinavian Journal of Psychology, 42, 313-331.

Şahin, F., ve Gürbüz, S. (2012). Kültürel zekâ ve öz-yeterliliğin görev performans1 ve Örgütsel Vatandaşlık Davranışı Üzerinde Etkisi: Çokuluslu Örgüt Üzerinde Bir Uygulama, (IŞGÜÇ) The Journal of Industrial Relations and Human Resources, 14(2), 123-140.

Şahin, F., Gürbüz, S., Köksal, O. ve Ercan, Ü. (2012). Kültürel Zekâ, Duygusal Zekâ ve Sosyal Zekâ'dan Farklı mıdır?, 11. Ulusal Isşletmecilik Kongresi, 356365 .

Şimşek, A.H., Öztürk, İ. (2018). Kültürel Zekâ ve Liderlik Arasındaki İlişsinin Analizi: Hastane Yöneticileri Örneği. Ekonomi Bilimlerinde Güncel Akademik Çalışmalar içinde (ss. 181-191). Gece Kitaplığ 1 , Ankara.

Thomas, D. ve Inkson, K. (2004). Cultivating Your Cultural Intelligence, Security Management, 48(8), 30-33.

Thomas, D.C., Elron, E., Stahl, G., Ekelund, B.Z. Ravlin, R.C. ve Cerdin, J. vd. (2008). Cultural Intelligence: Domain and Assessment. International Journal of Cross Cultural Management, 8(2), 123-143. 
Thorndike, E. L. (1920). Intelligence and Its Use, Harper's Magazine, 140, 227 235.

Türk Dil Kurumu (2019). Güncel Türkçe Sözlük, http://www.tdk.gov.tr/index.php?option=com_bts\&view=bts\&kategori1=verit bn\&kelimesec $=214144$, (Erişim Tarihi: 10.04.2019).

Uludağ, E. ve Deveci, G. (2018). Hemşirelik Öğrencilerinin Kültürel Zekâlarının Değerlendirilmesi, Gümüşhane Üniversitesi Sağllk Bilimleri Dergisi, 7(1), 7076.

Ülker, Ç. (2016). Meslek Yüksekokulu Öğrencilerinin Sosyal Zekâ ve İletişim Becerilerinin Farklı Değişkenler Açısından İncelenmesi, Yüksek Lisans Tezi, Nişantaşı Üniversitesi Sosyal Bilimler Enstitüsü.

Vedadi, A., Kheiri, B. ve Abbasalizadeh, M. (2010). The Relationship between Cultural Intelligence and Achievement: A Case Study in An Iranian Company, Iranian Journal of Management Studies, 3(3), 25-38.

Ward, C. ve Fischer, R. (2008). Personality, Cultural Intelligence, and Crosscultural Adaptation, Handbook of Cultural Intelligence, 159-173.

Wechsler, D. (1958). The Measurement and Appraisal of Adult Intelligence, (4th ed.) Baltimore: Williams \& Wilkins.

Wedeck, J. (1947). The Relationship between Personality and "Psychological Ability", British Journal of Psychology, 37, 133-151.

Wu, P. C. ve Ang, S. H. (2011). The Impact of Expatriate Supporting Practices and Cultural Intelligence on Cross-cultural Adjustment and Performance of Expatriates in Singapore, The International Journal of Human Resource Management, 22(13), 2683-2702.

Yan, Y. ve Child, J. (2004). Investors' Resource Commitments and Information Reporting Systems: Control in International Joint Ventures, Joumai of Business Research, 57, 361-371.

Yeşil, S. (2010). 21. Yüzy1lın Küresel Örgütleri için Kültürel Zekâ, Ç.Ü. Sosyal Bilimler Enstitüsü Dergisi, 19(2), 147-168. 